\title{
Contestation and Responsiveness in EU Council Deliberations
}

\author{
Sara B. Hobolt and Christopher Wratil
}

Accepted for publication in Journal of European Public Policy

\begin{abstract}
Decision-making in the Council of the European Union appears highly consensual at the voting stage. However, we focus on Council deliberations, where we find higher levels of contestation. What drives government opposition in the Council? Using a novel approach of studying the Council through video footage of its public deliberations (DICEU - Debates in the Council of the European Union), we demonstrate that contestation between governments is, at least in part, driven by their responsiveness to domestic public opinion. Analysing deliberations on legislative packages in the Economic and Financial Affairs Council between 2010 and 2015, we show that governments are responsive to public opinion when setting out their policy positions, but primarily when the policy issues are salient domestically. Our study thus contributes to our understanding of government responsiveness in the EU.
\end{abstract}

Key words: Contestation, Council, Public Opinion, Deliberations, Responsiveness

Word count: 7,500 
What drives the positions taken by governments in the Council of the European Union (henceforth, 'the Council')? Voting records suggest that Council decision-making is highly consensual with very little government opposition to legislative proposals (Hagemann et al. 2017; Heisenberg 2005; Hosli et al. 2011; Novak 2013). However, we know that European Union (EU) policies have become more contested in recent decades, not least in response to the Eurozone and refugee crises (Börzel and Risse 2018; Cramme and Hobolt 2014). The EU has also become more politicised in the domestic sphere, as the issue has been mobilised by issue entrepreneurs (De Wilde and Zürn 2012; Hobolt and De Vries 2015; Hooghe and Marks 2009). Studies point to considerable disagreement between governments at various stages of the negotiation process (Häge 2013; Kleine 2013; Thomson 2011). This raises the question of the degree and timing of contestation between governments in the Council and importantly, what drives such conflict?

To examine these questions, we adopt a novel empirical approach. Specifically, we analyse negotiation positions of governments in the Council by coding the official video recordings of public deliberations in the Council, the so-called Debates in the Council of the European Union (DICEU) database (see Wratil and Hobolt 2019). This database allows us to systematically measure conflict in the Council during the different stages of legislative negotiations, and show that intergovernmental contestation is highest at the early stages of negotiations. We then examine the causes of this contestation. Several studies have examined the drivers of disagreement in the Council, using voting, policy statements, document or interview data, focusing on diverging economic interests and geographical divisions (e.g. Bailer et al. 2015; Thomson 2011; Zimmer et al. 2005). While these factors are undoubtedly important in explaining conflict in the Council, we focus on the role of domestic electoral politics. Specifically, we argue that public opinion influences government positions in public 
deliberations, especially if issues are salient domestically. Recent work has shown that governments adjust their initial policy positions at the beginning of EU negotiations to the 'public mood' (Wratil 2018) and use opposition votes in the Council at the end of the legislative process to 'signal responsiveness' to Eurosceptic domestic electorates (Hagemann et al. 2017). Moreover, other research has demonstrated that the Council now pays more attention to issues that the public considers salient and that public opinion also influences how many and which policies are agreed at the EU level (Alexandrova et al. 2016; Schneider 2018; Toshkov 2011; Wratil 2019).

In this paper, we build on this work to demonstrate the impact of public preferences during Council negotiations. Importantly, we present the first analysis of government responsiveness in the Council that measures public opinion not as a general 'public mood' for policy, but as the public support for concrete and specific legislative proposals. Empirically, we analyse 58 debates in the Economic and Financial Affairs Council (ECOFIN) from 2010 to 2015. We thus focus on a significant area of policy-making with considerable variation in the degree of politicisation across issues, ranging from technical discussions on specific taxation policies of companies to the more politicised issues of the financial transaction tax and the EU budget. As we expect that governments have greater incentives to be responsive on issues that are domestically salient, we can leverage this variation to examine the moderating effect of issue salience on government responsiveness.

Our findings show that governments are responsive to issue-specific public preferences, particularly when the policy issue is salient domestically. This paper thus contributes to the literature on EU policy-making by analysing an original dataset on Council negotiations and by showing how domestic politics and politicisation shape the positions taken by governments in the Council. 


\section{Contestation and responsiveness in the Council}

The Council is the EU's co-legislature (jointly with the European Parliament) where national ministers negotiate and subsequently vote on legislative proposals put forward by the European Commission. Legislative bargaining in the Council used to be highly secretive and has been described as characterised by an 'informal culture of consensus' (Heisenberg 2005: 68). As information on voting behaviour in the Council has become available, studies have shown that governments cast less than 2 percent of all votes against legislative proposals (Hagemann et al. 2017; Hosli et al. 2011). At the pre-negotiation stages, however, studies have demonstrated that disagreement among member states on legislative proposals is far more pronounced than suggested by voting data. Most notably, the 'Decision Making in the European Union' (DEU) project has collected an impressive database of governments' initial negotiation positions in the Council based on interviews with officials on controversial issues (Thomson et al. 2006; Thomson et al. 2012). While the DEU dataset documents high levels of disagreement among member states before negotiations start, we know less about contestation during the Council negotiations. The focus of this paper is on the nature and causes of contestation during these negotiations.

A number of studies seeks to explain voting behaviour, such as Bailer et al. (2015), who demonstrate that opposition votes can largely be attributed to economic explanations, notably domestic specialised interests. Some work has argued that governments' left-right ideology shapes their behaviour in the Council (Hagemann and Høyland 2008), while this has been disputed by other studies (Bailer et al. 2015; Hosli et al. 2011). Moreover, the DEU data has also

provided important insights into government positions in the Council, including that 
geographically closer member states are more likely to vote together and that there is a cleavage between 'old' and 'new' member states (Thomson 2009), between the North and the South (Thomson 2011) and between net beneficiaries and net contributors to the EU budget (Zimmer et al. 2005).

These voting- and interview-based studies have thus generated important insights into the national interests that drive position-taking and opposition in the Council, yet they are largely silent on how domestic electoral politics may influence contestation in the Council. Indeed, the general assumption is that governments are largely insulated from electoral pressures when they legislate in the Council and that public preferences play a very limited role (see e.g. Bailer et al. 2015). Some recent work has challenged this assumption by showing that governments do respond to the 'public mood' on Europe when legislating in the Council. Using DEU data, Wratil (2018) shows that governments are responsive to public opinion on left-right issues in the run-up to national elections and on European integration issues when they are salient. Moreover, Hagemann et al.'s (2017) study of Council voting demonstrates that governments are more likely to oppose legislative proposals that expand the EU's authority when their domestic electorates are sceptical about the EU, especially when the issue of European integration is salient in domestic party politics. This suggests that governments use opposition in the Council to signal to Eurosceptic electorates that they are responsive to their concerns. Kleine (2013) has shown that member states in the EU use informal governance to accommodate governments under unexpectedly strong domestic pressure. Moreover, Kleine and Minaudier (2017) demonstrate that upcoming national elections in the large member states delay decision-making in the Council. These studies thus provide evidence that governments in the Council take domestic public opinion into account, especially when electoral sanctioning is more likely. 
In this paper, we extend this work by exploring substantive government responsiveness on specific policies. We present the first study of whether the positions governments adopt in the Council are responsive not only to the general 'public mood,' but also to public preferences on specific policies that are negotiated in the Council. For this purpose, we use cross-national public opinion data from the Eurobarometer on policy-specific items relating to five legislative packages. Moreover, we investigate a different stage in the legislative process by looking at the entire process of official intergovernmental negotiations at the ministerial level instead of pre- or post-negotiation stages. Specifically, we make use of an original dataset of the public deliberations of legislative packages in the ECOFIN Council between 2010 and 2015, which covers virtually all official deliberations between national ministers and their deputies (see also Wratil and Hobolt 2019).

Our theoretical expectations of government responsiveness in the Council build on the notion that government responsiveness to public preferences is driven by 'anticipatory representation', as governments focus on what they think voters will reward in the next election rather than what they promised during the campaign of the previous election (Erikson et al. 2002; Mansbridge 2003; Stimson et al. 1995). The reason is very simply: the fear of electoral sanction if they ignore public opinion. As a guide to what the electorates may want in the next election, governments are likely to pay attention to the current state of public preferences on an issue. Our expectation is therefore that governments in the Council are more likely to support a proposal that is supported by a majority of their domestic electorate and more likely to oppose it if most voters at home oppose it, just as they are when making policies domestically. Crucially, however, we primarily expect that governments will pay attention to domestic public opinion if doing so may influence their electoral fortunes, i.e. if there is a possibility that they will be held to account. In some systems, and on some policy issues, 
governments actions are much less likely to be consequential at the ballot box. Comparative studies of responsiveness at the national level have found that in systems of low clarity of responsibility and limited information, where it is difficult for voters to identify policy shirking, elected representatives are also less responsive to public preferences (see Carey 2008; Powell and Whitten 1993; Wlezien and Soroka 2012). That means that we would generally expect lower levels of responsiveness in systems with low clarity of responsibility, such as the EU.

However, as policy debates in the EU become more politicised and more salient to the domestic public, we also expect that governments will be more responsive when deliberating in the Council. When EU policy-making is salient in the domestic public debate, governments may be concerned that 'unpopular' positions in the Council, or subsequent policies, can potentially be electorally costly in the next national election, as the media, interest groups, or competitors may raise voters' attention to the government's unresponsive behaviour. We thus expect that responsiveness to public preferences in the Council will occur primarily when the legislative issues at stake are salient in the domestic public sphere.

One may argue that despite increased transparency in the Council, there is still not sufficient attention paid to deliberations in the Council to incentivise responsive behaviour by governments. In his work on accountability in the EU, Naurin (2006: 91) distinguishes between transparency and publicity, arguing that publicity is necessary for accountability, since it means that the information is not only available, but 'the content of this information has also become known among the voters'. Our expectation is not that transparency of Council negotiations in and of itself guarantees publicity. Indeed, we are not expecting that ordinary voters watch videos of Council deliberations. But the fact that these negotiations are a matter of public record means that government positions could become known to voters, through the 
dissemination efforts of the media, other political parties or interest groups, and this means that there is a possibility that governments may be held to account for their stances in the Council. Governments may thus be concerned about the very possibility of publicity and its potential electoral consequences, which is likely greater in deliberations on issues that are salient domestically, and this encourages them to act more responsively. This leads to the following hypotheses:

H1: Governments are more disapproving of EU legislative proposals in the Council, the more public opinion at the domestic level opposes the proposals.

H2: The effect of public opinion on a government's policy positions in the Council is greater if the policy proposal is salient at the domestic level.

In the ensuing sections, we first describe our approach to measuring government positions and contestation in the Council and then we examine whether public preferences drive these positions.

\section{Measuring government positions and contestation in the Council}

In order to measure government positions and contestation in the Council, we rely on the DICEU dataset (Wratil and Hobolt 2019). DICEU is based on the analysis of video footage of public deliberations of the Council and is the first dataset that systematically makes available data on these deliberations. In 2006, the Council for the first time made video recordings of its legislative deliberations public, and since the Lisbon Treaty, the Council must deliberate in 
public when negotiating legislative files or discussing questions of strategic relevance, and all debates are video-streamed on the Council's website. Videos of public deliberations of the Council therefore provide important first-hand evidence on legislative bargaining in the EU, more akin to intergovernmental bargaining than plenary debates in legislatures. ${ }^{1}$ While a large part of these negotiations takes place outside the formal Council meetings (e.g. in COREPER and the working parties, or in informal settings), these deliberations constitute the highest level of the formal negotiation process.

In recent work, we have demonstrated the validity of DICEU data (Wratil and Hobolt 2019). In particular, we have shown that governments' ideal points scaled from videos yield meaningful and well-known conflict dimensions and that DICEU positions correlate highly with assessments of expert practitioners interviewed by the DEU project (e.g. staff from the permanent representations). The available DICEU data covers virtually all public legislative debates in the ECOFIN Council configuration between 2010 and 2015 (see Wratil and Hobolt 2019). This amounts to 89 debates. Human coders watched all debates and coded them according to a comprehensive codebook (see the Supplemental Material). As our main variable to measure contestation in the Council, we employ the 'General Approval' (V6) variable. This variable requires coders to identify a major dimension of approval versus disapproval within each debate. Typically, debates are structured and moderated by the Council presidency. Styles of presidents vary, but they will normally outline a topic for debate at the beginning of the meeting and in broad terms this topic is almost without exception about approval or disapproval of either a legislative proposal presented by the Commission,

\footnotetext{
${ }^{1}$ As an illustration, we have included several extracts from the debates in the Supplemental Material.
} 
the state of play on a proposal, or the state of negotiations with the European Parliament (EP). ${ }^{2}$ In fact, many presidencies close their entry statement by asking whether delegations 'approve' of a proposal.

Coders used a 5-point Likert item to assess the degree of approval of each actor speaking in the debate from 'full approval' (1) to 'full disapproval' (5). The general Disapproval variable therefore always indicates the degree to which a government disapproves of the state of negotiations in each debate (either when a proposal is presented, amended later, or discussed with other institutions). The inter-coder reliability of this variable is high (Krippendorff's alpha $=0.82$ ). Our data allow us to investigate the levels of contestation at different stages of the negotiation process. For this purpose, we compare the share of governments that express disapproval ('more disapproval than approval' and 'full disapproval') in public deliberations at three different stages: 1) debates on the presentation of legislative proposals ('initial presentations'), 2) exchanges of views about the content of proposals ('policy debates'), and 3) debates leading to political agreement ('debates on political agreement'). $11 \%$ of our debates are initial presentations, $38 \%$ are policy debates, and $51 \%$ are on political agreement. As a fourth and final stage we also consider the share of governments that cast opposition votes ('no' or 'abstain') against proposals at the end of negotiations. ${ }^{3}$

\footnotetext{
${ }^{2}$ Note that the varying meanings of disapproval across debates and at different negotiation stages may lead to measurement error, which is why we control for the negotiation stage in all main models. ${ }^{3} 8$ debates were discussions of presidency work programmes, and hence no official votes on these matters are recorded and 23 debates were completed without an official vote or without reporting it. As a result, we lack voting data on 31 of our 89 (34\%) DICEU debates. This highlights that voting data neglects a substantial part of intergovernmental politics in the Council. In fact, we have no official Council votes on some of the most significant ECOFIN proposals discussed during the last years, most prominently the Commission's proposal for a financial transaction tax - the most frequently debated legislative proposal in the DICEU dataset (8 debates).
} 
Table 1 compares the level of disapproval in negotiations and votes across different packages of legislative proposals and negotiation stages. Specifically, we allocate legislative proposals into six packages: 'Financial transaction tax' (FTT), 'EU budget ${ }^{4 \prime}$, 'Banking union', 'Tax issues', 'European Fund for Strategic Investments' (EFSI), and 'Other'. ${ }^{5}$ The table shows that the most contested proposals during negotiations were on the FTT, with $34 \%$ of government interventions voicing disapproval. As a result, none of the FTT proposals was ever discussed in a debate on political agreement or put to a vote. Importantly, while there is substantial variation between legislative packages, on average, contestation diminishes over the course of negotiations falling from 30\% disapproving interventions in initial presentation debates to $17 \%$ in debates on political agreement. Nevertheless, even this figure of disapproval is more than four times higher than the $3.8 \%$ opposition votes observed at the voting stage.

Table 1: Comparing contestation during negotiations and in voting

\begin{tabular}{c|ccc|c|c}
\hline \multirow{2}{*}{$\begin{array}{c}\text { Legislative } \\
\text { packages }\end{array}$} & \multicolumn{4}{|c|}{ Disapproval in negotiations } & $\begin{array}{c}\text { Opposition } \\
\text { votes }\end{array}$ \\
& Initial presentations & Policy debates & $\begin{array}{c}\text { Debates on political } \\
\text { agreement }\end{array}$ & $\begin{array}{c}\text { All } \\
\text { stages }\end{array}$ & \\
\hline \hline FTT & $32 \%$ & $34 \%$ & No debate & $34 \%$ & No voting \\
EU budget & $41 \%$ & No debate & $25 \%$ & $30 \%$ & $5 \%$ \\
Banking union & $17 \%$ & $11 \%$ & $13 \%$ & $13 \%$ & $1 \%$ \\
Tax issues & No debate & $25 \%$ & $24 \%$ & $24 \%$ & $0 \%$ \\
EFSI & $15 \%$ & $30 \%$ & $0 \%$ & $12 \%$ & No voting \\
Other & $12 \%$ & $17 \%$ & $9 \%$ & $14 \%$ & $2 \%$ \\
\hline All debates & $30 \%$ & $22 \%$ & $17 \%$ & $20 \%$ & $3.8 \%$ \\
\hline
\end{tabular}

Note: Figures are shares of all government interventions / all votes cast by governments.

\footnotetext{
${ }^{4}$ Note that ECOFIN deals primarily with the annual budget and not the multiannual financial framework.

${ }^{5}$ We chose these categories guided by the availability of public opinion data on each of them.
} 
This provides some novel quantitative evidence that governments resolve conflict over the course of negotiations. At the same time, it highlights that even towards the end of negotiations some governments are still disapproving of the state of affairs but nonetheless cast a 'yes' vote on the act.

\section{Data and operationalisation}

What drives this contestation in Council deliberations? To test whether government disapproval in the Council is shaped by public opinion, we use Disapproval (running from 1 to 5 , with higher values indicating more disapproval) as our main dependent variable. Crucially, we also need a measure of policy-specific public opinion. The key challenge is to identify question items from public opinion surveys that ask respondents directly about their opposition to or support of EU policies that were discussed in the ECOFIN configuration, ideally at several time points. We use the Eurobarometer surveys as they regularly include questions on the legislative files the Commission prepares. We are able to identify suitable public opinion items for a total of five legislative packages (see above), relating to 58 out of the 89 debates in the DICEU dataset. These five packages cover $72 \%$ of all legislative debates and $79 \%$ of all debating time in ECOFIN in our period of study.

First, for debates on the FTT we use a question that asks respondents: 'Thinking about reform global financial markets, please tell me whether you are in favour or opposed to the following measures to be taken by the EU.' One item to rate is 'The introduction of a tax on financial transactions'. The advantage of this question is that it clearly asks for a view on FTT implemented by the EU. Second, for debates on cross-national tax issues (e.g. automatic 
exchange of information, common standards) we use the same question with the item 'Tougher rules on tax avoidance and tax havens'. This yields a measure of public opposition to tougher EU tax regulation, which was the main purpose of EU initiatives in this area. Third, for all public debates on the EU's banking union, we use the following item from the same battery: 'The introduction of a tax on profits made by banks'. While this item does not directly ask for opposition to the banking union, it taps into public attitudes on whether banks keep 'too much profit' for themselves. Since many of the legislative acts under the banking union umbrella (e.g. CRD IV, single resolution fund) ultimately impose costly regulation on banks with tax-like balance sheet effects, we use opposition to this item as a measure of opinion on the banking union.

Fourth, to measure public opposition to the EFSI we use disagreement with the following statement: 'Public money should be used to stimulate private sector investment at EU level'. Since the European Investment Bank itself defines the EFSI through its aim 'to mobilize private investment in projects which are strategically important for the EU' (http://www.eib.org/efsi/), the item should be an appropriate measure of public opposition to the EFSI. Fifth, we measure public opinion on the annual EU budget amendments by a question asking respondents 'With which of the following two statements do you most agree?'. Respondents could either pick 'The EU should have greater financial means given its political objectives' or alternatively 'The EU's political objectives do not justify an increase in the Union's budget'. We operationalise public opposition to budget amendments (generally implying higher appropriations) through the share of respondents choosing 'The EU's political objectives do not justify an increase in the Union's budget'.

We measure mean opinion on these Eurobarometer items in each country using poststratification weights, with higher values indicating more opposition to (or less support for) 
the EU policy proposal. Specifically, we use estimates from the last survey (before the respective Council debate) in which the item was asked. ${ }^{6}$ Using past opinion ensures that public preferences are measured prior to the governments' deliberations. Moreover, we use a z-score standardisation for each of the five different items, which corrects for the different response scales, and combine them in a single variable. This Public opposition variable indicates opposition in a country in terms of standard deviations from mean opposition to this legislative package across countries and debates (i.e., $z_{i, j, d}=\frac{P O_{i, j, d}-\overline{P O_{j}}}{\sigma\left(P O_{j}\right)}$, where $P O_{i, j, d}$ is public opposition in country $i$ on package $j$ at the time of debate $d$ ).

To test our second hypothesis of the conditioning effect of salience on responsiveness, we collect data on the national media coverage of the five legislative packages for which we have public opinion data. Dolezal et al. (2016: 43) convincingly argue that media coverage is the best indicator of EU politicisation in today's 'audience democracies', in which media 'play a central role of intermediation between citizens and the state'. Hence, we use media attention as a proxy measure for issue salience, and we expect that public opinion should matter more for governments' behaviour in Brussels when negotiating issues that are more salient. We are thus interested in capturing media attention to an issue as a general indicator of the public salience of that issue, rather than as a measure of media effects per se. ${ }^{7}$ While media coverage is difficult to measure for each and every piece of EU legislation, we are able to measure the media coverage of the policy issues discussed in our five legislative packages. Specifically, we

\footnotetext{
${ }^{6}$ The number of survey waves available varies between the opinion measures (e.g. from only two waves for the EU budget to frequent half-yearly estimates of opinion for the FTT). In the Supplemental Material, we also show that our results hold when interpolating between opinion surveys and using a six-month lag or current opinion.

${ }^{7}$ We acknowledge that media attention is a noisy indicator of public salience. In some instances, the very failure of governments to respond to public opinion may fuel media stories. In such cases, attention is more a consequence than a predictor of responsiveness.
} 
count the number of articles that refer to the legislative package and its contents in major newspapers in Austria, France, Germany, Ireland, Italy, Malta, Netherlands, Spain and the United Kingdom in the six-month period preceding a Council meeting. This is achieved by creating lists of search terms and patterns (e.g. distance between words) for each package that delineate articles referring to the topics of the legislative package from those dealing with adjacent issues (for a very similar approach, see Reh et al. 2013). Details are in the Supplemental Material.

Figure 1: Media coverage by legislative package

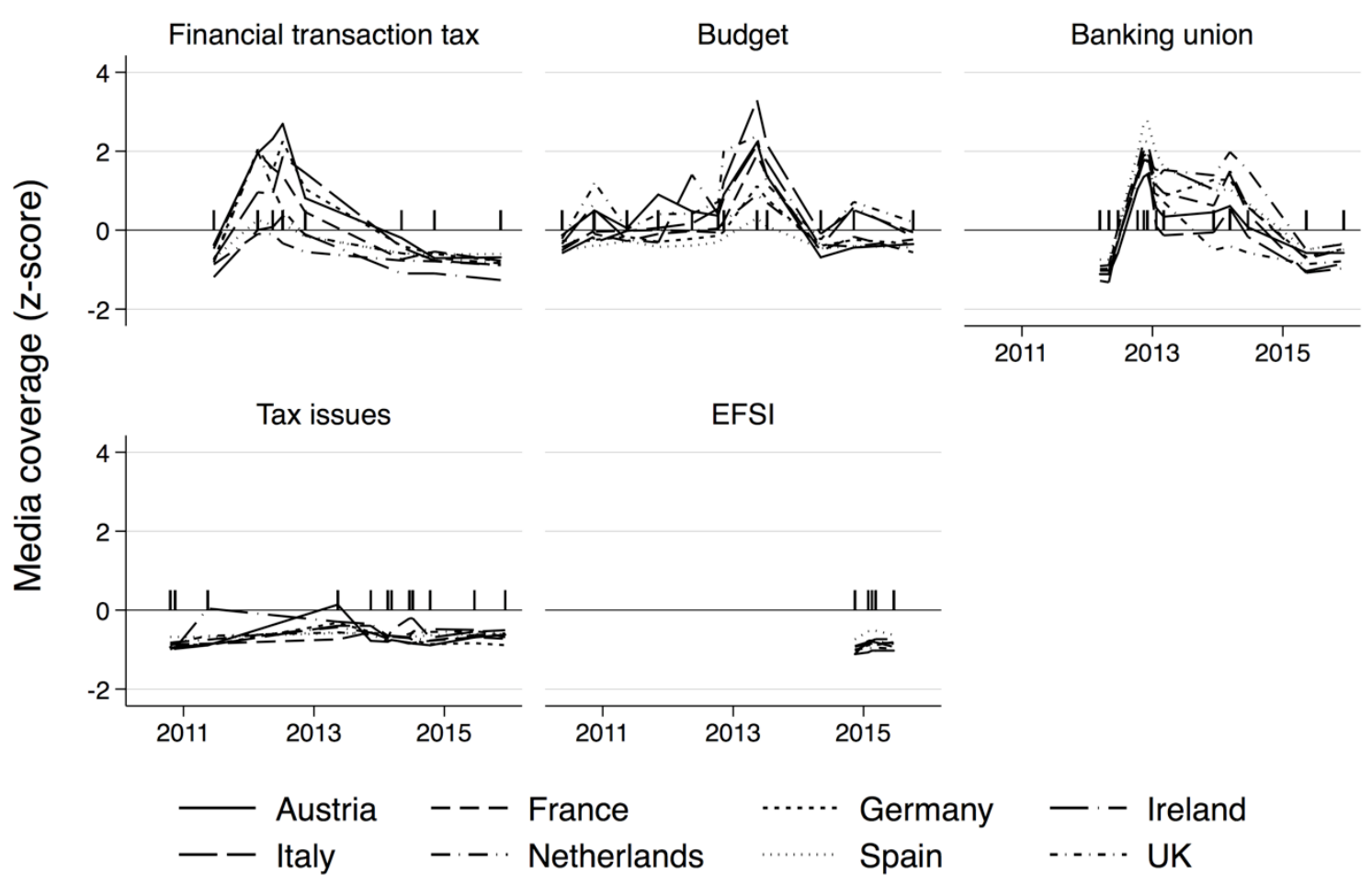

Notes: Vertical bars indicate dates of debates on the package. 
Figure 1 plots media coverage (z-standardised within countries) over time and separately for each legislative package. ${ }^{8}$ Most remarkably, the patterns of media coverage are very similar across countries for all packages. While media attention to tax issues and the EFSI is below average (' 0 '-line) in all countries at (almost) all times, there are temporal peaks of media attention at 1 to 2 standard deviations above the mean for the budget, the banking union, and the FTT in most countries. This is indicative of the higher domestic salience of these proposals that have the chance to be disproportionately covered in the media at times. Since media attention is a proxy for public salience and we were only able to obtain media data in nine out of $28 \mathrm{EU}$ countries, we focus on a binary classification delineating more salient from less salient legislative packages. Specifically, we use a dummy variable Salient legislative package that is ' 1 ' for debates on the FTT, the budget and the banking union and ' 0 ' for debates on tax issues and the EFSI, which captures the contrast between 'high salience' and 'low salience' packages. $^{9}$

We also control for several factors that have been found to influence government behaviour in the Council and that may also be correlated with public opinion. First, we include a measure of the government parties' positions on economic policy matters as well as European integration. This addresses findings that government ideology matters for Council politics (Hagemann and Høyland 2008). It also assures that our estimates capture actual responsiveness to public opinion (i.e., anticipatory representation), and not simply changing

\footnotetext{
${ }^{8}$ Note that we omit data for Malta from Figure 1, since the Maltese media data are very noisy due to the fact that the average number of articles on a legislative package in the six-month period preceding a Council meeting is just 3.6, while it is well above 39 for all other countries.

${ }^{9}$ In the Supplemental Material we show that when we only use our sample of nine countries for which we have media data, and classify each country-package dyad according to whether average media coverage of a package in a country was below or above the country mean (as dummy variable), we obtain substantively the same results as in our main analyses. The same is the case when using an alternative measure of salience based on "don't know" responses in the Eurobarometer surveys.
} 
government behaviour due to changes in government composition that may be highly correlated with fluctuations in opinion (see Stimson 1999). For economic matters, we use the Comparative Manifesto Project's (CMP) coding of the government parties' election manifestos on the planned economy scale ('planeco') (Volkens et al. 2018). This scale is constructed as the percentage of quasi-sentences that parties devote to the topics of 'Market Regulation' (per403), 'Economic Planning' (per404), and 'Controlled Economy' (per412). This relates most precisely to our legislative packages that deal with regulation (e.g. tax regulation) and states' intervention into the economic realm (e.g. banking union, FTT). In addition, we also use a proanti integration scale that is the percentage of positive quasi-sentences minus the percentage of negative quasi-sentences on European integration (per108 - per110). Where applicable we obtain aggregated positions of government parties by seat-weighting the manifesto estimates of the individual coalition partners.

In addition, we also control for governments' annual receipts from the EU budget (percentage of GDP) as well as for annual national unemployment and inflation rates. On the one hand, this takes account of findings on the decisive role of national economic interests for government behaviour in the Council (Bailer et al. 2015; Zimmer et al. 2005). On the other hand, it also ensures that our estimates on public opinion represent more than fluctuations in the economy that have the potential to move opinion (e.g. Stevenson 2001). Last, we control for a cleavage between small and big countries with a measure of a country's population (in million inhabitants) (Schure and Verdun 2008; Thomson 2011). This accounts, inter alia, for the fact that smaller countries have a much more specialised and less diversified economy than big countries. 
Last, we also control for the negotiation stage, since we have shown above that governmental disapproval is clearly higher in initial presentations (reference category) than in policy debates or debates on political agreement.

\section{Analysis and Results}

To analyse responsiveness in the Council we use mixed effects linear regressions with Disapproval as the dependent variable (running from 1 to 5). We account for potential unobserved heterogeneity between countries and debates with different random and fixed effects specifications. Since we face non-trivial amounts of missing values (e.g. 9 percent of the public opinion data), mainly due to the incompleteness of the Eurobarometer and the CMP data, we multiply impute these values using chained equations with predictive mean matching, creating 30 multiple-imputed datasets (see the Supplemental Material). The results are reported in Table 2. Whereas Models 1 and 2 are specified with random effects for debates and countries, Model 3 uses fixed effects for countries, ruling out country-level time-invariant confounders.

To test $\mathrm{H} 1$ we first include just the main term of public opinion in Model 1. This reveals that, on average, governments disapprove more strongly of legislative proposals if public opposition is greater. To test hypothesis $\mathrm{H} 2$ we include an interaction term between public opposition and salient legislative packages in Models 2 and 3. In both models the interaction term is positive and statistically significant. This indicates that the effect of public opposition on governments' disapproval of EU policy proposals in the Council is stronger for those legislative packages that receive high domestic media attention at times. In fact, the effect of 
public opposition is not significant but still positive for packages with lower salience ( $p=$ $0.16)$.

Table 2: Models of governmental disapproval

\begin{tabular}{|c|c|c|c|}
\hline & Model 1 & Model 2 & Model 3 \\
\hline Public opposition & $\begin{array}{l}0.342 \\
(0.047) * *\end{array}$ & $\begin{array}{l}0.112 \\
(0.080)\end{array}$ & $\begin{array}{l}0.107 \\
(0.080)\end{array}$ \\
\hline Salient legislative package & & $\begin{array}{l}0.260 \\
(0.191)\end{array}$ & $\begin{array}{l}0.341 \\
(0.212)\end{array}$ \\
\hline Public opposition * Salient legislative package & & $\begin{array}{l}0.321 \\
(0.094) * *\end{array}$ & $\begin{array}{l}0.326 \\
(0.096)^{* *}\end{array}$ \\
\hline Government planeco position & $\begin{array}{l}-0.059 \\
(0.015) * *\end{array}$ & $\begin{array}{l}-0.056 \\
(0.015)^{* *}\end{array}$ & $\begin{array}{l}-0.063 \\
(0.020)^{* *}\end{array}$ \\
\hline Government EU position & $\begin{array}{l}-0.006 \\
(0.022)\end{array}$ & $\begin{array}{l}-0.011 \\
(0.022)\end{array}$ & $\begin{array}{l}-0.009 \\
(0.026)\end{array}$ \\
\hline Receipts from EU budget & $\begin{array}{l}-0.076 \\
(0.036) *\end{array}$ & $\begin{array}{l}-0.070 \\
(0.036)\end{array}$ & $\begin{array}{l}0.049 \\
(0.078)\end{array}$ \\
\hline Unemployment rate & $\begin{array}{l}-0.031 \\
(0.012) *\end{array}$ & $\begin{array}{l}-0.029 \\
(0.012)^{*}\end{array}$ & $\begin{array}{l}0.013 \\
(0.028)\end{array}$ \\
\hline Inflation rate & $\begin{array}{l}-0.062 \\
(0.041)\end{array}$ & $\begin{array}{l}-0.080 \\
(0.043)\end{array}$ & $\begin{array}{l}-0.049 \\
(0.047)\end{array}$ \\
\hline Population & $\begin{array}{l}0.004 \\
(0.003)\end{array}$ & $\begin{array}{l}0.005 \\
(0.003)\end{array}$ & \\
\hline Policy debates & $\begin{array}{l}-0.580 \\
(0.279) *\end{array}$ & $\begin{array}{l}-0.536 \\
(0.277)\end{array}$ & \\
\hline Debates on political agreement & $\begin{array}{l}-0.907 \\
(0.249) * *\end{array}$ & $\begin{array}{l}-0.874 \\
(0.248)^{* *}\end{array}$ & \\
\hline Constant & $\begin{array}{l}3.615 \\
(0.290) * *\end{array}$ & $\begin{array}{l}3.390 \\
(0.319)^{* *}\end{array}$ & $\begin{array}{l}1.835 \\
(0.387)^{* *}\end{array}$ \\
\hline$N$ & 751 & 751 & 751 \\
\hline Number of countries & 28 & 28 & 28 \\
\hline Number of debates & 58 & 58 & 58 \\
\hline Fixed effects & & & Countries \\
\hline Random effect & $\begin{array}{l}\text { Debates, } \\
\text { Countries }\end{array}$ & $\begin{array}{l}\text { Debates, } \\
\text { Countries }\end{array}$ & Debates \\
\hline
\end{tabular}

Notes: All are mixed effects regressions; Standard errors in parentheses; Multiple imputation estimates using chained equations with predictive mean matching $(m=30)$; $* p<0.05 ; * * p<0.01$. 
In Figure 2 we plot the effect of public opposition for legislative packages with low (left panel) versus high (right panel) salience based on the results from Model 2. While public opposition at home is virtually irrelevant to governmental disapproval in the Council for legislative packages with comparatively low domestic salience, governments are very sensitive to the public if the package is highly salient. This is key evidence for hypothesis $\mathrm{H} 2$. Note that due to our use of country fixed effects in Model 3, these results are not driven by cross-national differences but by changes in public opposition within countries over time and across legislative packages.

Figure 2: Effect of public opposition on governmental disapproval by issue salience

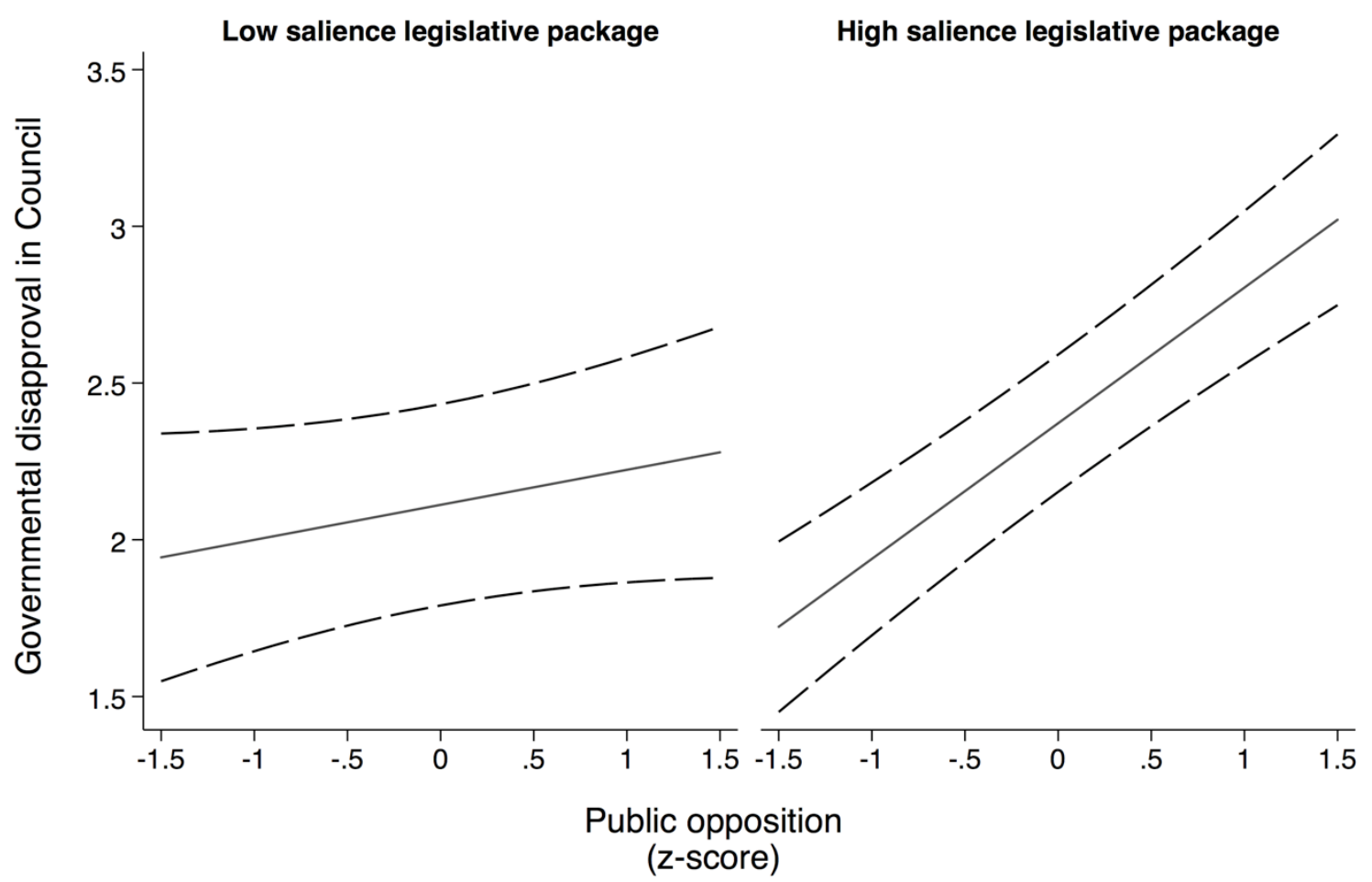

Notes: 95\% confidence intervals as dashed lines. 
In terms of the control variables the effect of the government's planeco position is most remarkable: government parties that have stressed a preference for more economic planning and economic regulation in their election manifestos are more approving of the major ECOFIN policy proposals in the period 2010 to 2015 . While this finding is in line with our theoretical expectations, since projects like the FTT, tax issues, or the banking union are clearly targeted at more tightly regulating economic activities, it is important evidence for the idea that party politics matters in the Council (e.g. Hagemann and Høyland 2008), and parties are engaging in mandate fulfilment at the EU level (Franchino and Wratil 2019). In contrast, the evidence for economic explanations of governments' preferences is more mixed: governments with higher unemployment at home are more approving of the state of negotiations (at least in Models 1 and 2), but the EU budget position and inflation do not matter significantly. As expected, we find significantly less governmental disapproval in debates on political agreement.

One concern about our models is the pooling of different question items in a single public opposition variable. While this provides us with the statistical power to test our hypotheses (especially, H2), we would like to exclude the possibility that it drives any results. Hence, we also estimate separate linear regression models for each of our five packages using the original public opinion items with varying scales. This also allows us to use varying sets of control variables that are more specific to each of the legislative packages. Moreover, the models do not include the fixed effects for the negotiation stage nor the random effect for debates, since only a few debates per package are held (see details in the Supplemental Material). In Figure 3 we plot the effect of public opposition for each package. This reveals that the effect of public opposition is strongest on the FTT and the EU budget. In these cases, 
the coefficients on public opposition are also statistically significant, for the banking union it is close to significance $(p=0.11)$. For the two other packages, the relationship between opposition and governmental disapproval is positive but far from statistical significance. Given that these three packages are also the packages that we classified with high domestic salience, these findings are in line with our hypotheses.

Figure 3: Effect of public opposition on governmental disapproval by legislative package
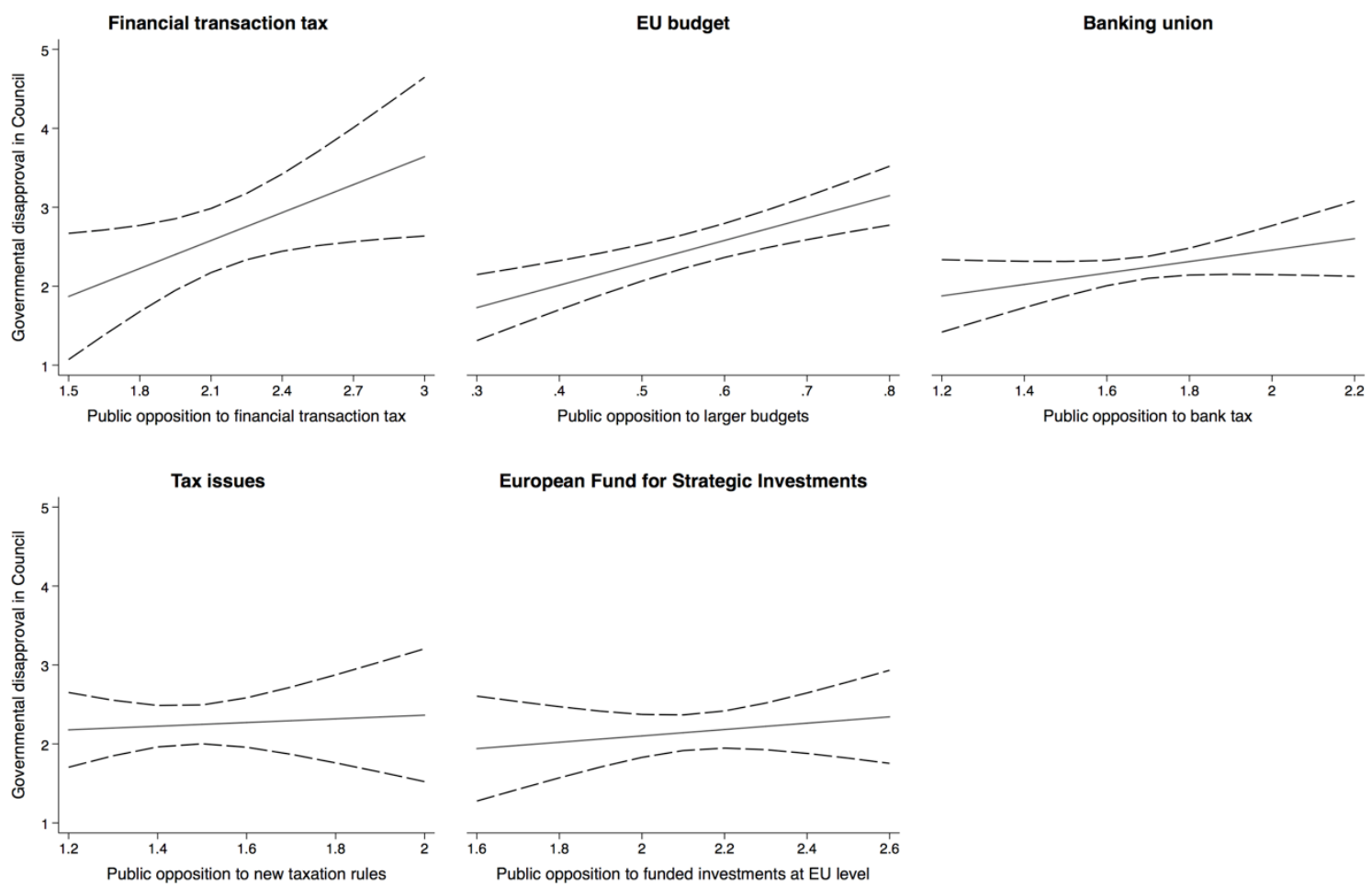

European Fund for Strategic Investments

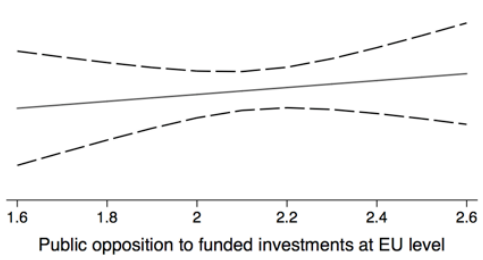

Notes: 95\% confidence intervals as dashed lines.

In the Supplemental Material, we perform several robustness and sensitivity analyses. In particular, we report results with different classifications of salient legislative packages, different operationalisations of opinion, using ordered instead of linear regression, and 
estimating the models without multiple imputation and control variables. We also address concerns about reversed causality in the relationship between governments' position-taking in the Council and public opposition. All these tests support our core results.

\section{Conclusion}

The EU's primary legislative chamber, the Council, used to be highly secretive. But recent transparency reforms have created new avenues to examine the drivers of intergovernmental conflict. This paper takes advantage of a novel dataset on public televised deliberations in the Council to examine the nature and domestic drivers of contestation. We demonstrate that contestation is highest at the early stages of the negotiations, and that government contestation is shaped by domestic opposition when negotiating salient legislative issues. This paper thus makes several contributions to the literature on legislative behaviour in the Council.

First, we present results from an original database on governments' legislative positions (DICEU). While most of the existing literature has focused on government positions at either the pre-negotiation stage (e.g. Thomson et al. 2006; Thomson et al. 2012) or the voting stage (e.g. Bailer et al. 2015; Hagemann et al 2017), we are able to analyse contestation over the whole course of formal Council deliberations. As expected, our findings show high levels of disagreement between governments at the initial stages of the negotiations and increasing consensus as the negotiations approach voting. This study thus provides an important bridge between the interview-based studies of pre-negotiation positions that have demonstrated high levels of conflict in the Council and studies focused on the final voting stage that have highlighted the high degree of consensus. 
The second contribution of this paper is to examine how domestic electoral politics influences contestation in the Council. Specifically, we use DICEU data to present the first study of government responsiveness to policy-specific public opinion in the EU context. There is a growing literature examining responsiveness to public opinion in the Council using mostly general Euroscepticism as an indicator of public preferences. Our results provide the first evidence that governments in the Council are not only responsive to general but also to issue-specific public opinion.

This finding primarily applies to governments' behaviour on legislative packages that are salient domestically. This demonstrates that governments in the Council are aware of public preferences and responsive to them when they fear that where ignoring the public opposition could be electorally costly. In other words, it suggests that the Council resembles a normal legislative body where politicians are responsive to public opinion, more than it does an opaque international institution insulated from electoral pressures. It is worth noting, however, that as we are focusing on the ECOFIN Council during a period when economic and financial issues were generally highly politicised across Europe, due to the Eurozone crisis, we may not necessarily find the same levels of responsiveness across all Council configurations or in other timeframes (e.g. when the EU was less politicised). Nonetheless, ECOFIN is a useful case study due to the still considerable variation in the salience of the legislative packages covered in our data - ranging from a high salience banking union to lower salience EU taxation issues. This variation allows us to draw more general inferences about the conditions under which governments in the Council are likely to be responsive to public opinion. Indeed, our findings suggest that responsiveness may be absent when the Council is debating issues that are not salient domestically. This suggests that governments 
are not insulated from domestic electoral incentives when they negotiate in the EU on domestically more salient matters, while public opposition plays a far smaller role on issues that are less salient. More generally, this study suggests that even actors in international organisations can be responsive to public opinion, when issues are politicized domestically. 


\section{References}

Alexandrova, P., Rasmussen, A. and Toshkov, D. (2016) 'Agenda Responsiveness in the European Council: Public Priorities, Policy Problems and Political Attention', West European Politics 39(4): 605-627.

Bailer, S., Mattila, M. and Schneider, G. (2015) 'Money Makes the EU Go Round: The Objective Foundations of Conflict in the Council of Ministers', Journal of Common Market Studies 53(3): 437-456.

Bølstad, J. (2015) ‘Dynamics of European Integration: Public Opinion in the Core and Periphery', European Union Politics 16(1): 23-44.

Börzel, T. A. and Risse, T. (2018) 'From the Euro to the Schengen Crises: European Integration Theories, Politicization, and Identity Politics', Journal of European Public Policy 25(1): 83-108.

Carey, J. M. (2008) Legislative Voting and Accountability, Cambridge University Press.

Cramme, O. and Hobolt, S. B. (eds) (2014) Democratic Politics in a European Union Under Stress, Oxford: Oxford University Press.

De Wilde, P. and Zürn, M. (2012) 'Can the Politicization of European Integration Be Reversed?', Journal of Common Market Studies 50(1): 137-153.

Dolezal, M., Grande, E. and Hutter, S. (2016) 'Exploring Politicisation: Design and Methods', in S. Hutter, E. Grande, and H. Kriesi (eds). Politicising Europe: Integration and Mass Politics. Cambridge University Press.

Erikson, R. S., MacKuen, M. B. and Stimson, J. A. (2002) The Macro Polity, Cambridge: Cambridge University Press.

Franchino, F. and Wratil, C. (2019) 'Representing the Compromise: How Institutions Serve Government Support Coalitions in European Union Policy-Making', European Journal of Political Research 1-24.

Häge, F. M. (2013) 'Coalition Building and Consensus in the Council of the European Union', British Journal of Political Science 43(3): 481-504.

Hagemann, S., Hobolt, S. B. and Wratil, C. (2017) 'Government Responsiveness in the European Union: Evidence From Council Voting', Comparative Political Studies 50(6): 850-876.

Hagemann, S. and Høyland, B. (2008) 'Parties in the Council?', Journal of European Public Policy 15(8): 1205-1221.

Heisenberg, D. (2005) 'The Institution of "Consensus" in the European Union: Formal versus Informal Decision-Making in the Council', European Journal of Political Research 44(1): 65-90.

Hobolt, S. B. and de Vries, C. E. (2015) 'Issue Entrepreneurship and Multiparty Competition', Comparative Political Studies 48(9): 1159-1185.

Hooghe, L. and Marks, G. (2009) 'A Postfunctionalist Theory of European Integration: From Permissive Consensus to Constraining Dissensus', British Journal of Political Science 
39(1): 1-23.

Hosli, M. O., Mattila, M. and Uriot, M. (2011) 'Voting in the Council of the European Union after the 2004 Enlargement: A Comparison of Old and New Member States', Journal of Common Market Studies 49(6): 1249-1270.

Kleine, M. (2013) Informal Governance in the European Union. How Governments Make International Organizations Work, Ithaca: Cornell University Press.

Kleine, M. and Minaudier, C. (2017) 'Negotiating under Political Uncertainty: National Elections and the Dynamics of International Co-operation', British Journal of Political Science 1-23.

Mansbridge, J. (2003) 'Rethinking Representation', American Political Science Review 97(04): 515-528.

Mattila, M. (2004) 'Constested Decisions: Empirical Analysis of Voting in the European Council of Ministers', European Journal of Political Research 43(1): 29-50.

Mattila, M. (2009) 'Roll Call Analysis of Voting in the European Union Council of Ministers after the 2004 Enlargement', European Journal of Political Research 48(6): 840-857.

Naurin, D. (2006) ‘Transparency, Publicity, Accountability - The Missing Links', Swiss Political Science Review 12(3): 90-98.

Novak, S. (2013) 'The Silence of Ministers: Consensus and Blame Avoidance in the Council of the European Union', Journal of Common Market Studies 51(6): 1091-1107.

Powell, G. B. and Whitten, G. D. (1993) ‘A Cross-National Analysis of Economic Voting: Taking Account of the Political Context', American Journal of Political Science 37(2): 391414.

Reh, C., Heritier, A., Bressanelli, E. and Koop, C. (2013) 'The Informal Politics of Legislation: Explaining Secluded Decision Making in the European Union', Comparative Political Studies 46(9): 1112-1142.

Schneider, C. J. (2018). The Responsive Union: National Elections and European Governance. Cambridge University Press.

Schure, P. and Verdun, A. (2008) 'Legislative Bargaining in the European Union: The Divide between Large and Small Member States', European Union Politics 9(4): 459-486.

Stevenson, R. T. (2001) 'The Economy and Policy Mood: A Fundamental Dynamic of Democratic Politics?', American Journal of Political Science 45(3): 620-633.

Stimson, J. A. (1999) 'Party Government and Responsiveness', in A. Przeworski, S. C. Stokes, and B. Manin (eds). Democracy, Accountability, and Representation. Cambridge: Cambridge University Press, pp. 197-221.

Stimson, J. A., MacKuen, M. B. and Erikson, R. S. (1995) 'Dynamic Representation', American Political Science Review 89(3): 543-565.

Thomson, R. (2009) 'Actor Alignments in the European Union before and after Enlargement', European Journal of Political Research 48(6): 756-781.

Thomson, R. (2011) Resolving Controversy in the European Union. Legislative Decision-Making before and after Enlargement, Cambridge: Cambridge University Press. 
Thomson, R. et al. (2012) 'A New Dataset on Decision-Making in the European Union before and after the 2004 and 2007 Enlargements (DEUII)', Journal of European Public Policy 19(4): 604-622.

Thomson, R., Stokman, F. N., Achen, C. H. and König, T. (eds) (2006) The European Union Decides, Cambridge: Cambridge University Press.

Toshkov, D. (2011) ‘Public Opinion and Policy Output in the European Union: A Lost Relationship', European Union Politics 12(2): 169-191.

Volkens, A., Lehmann, P., Matthieß, T., Regel, S. and Weßels, B. (2018) The Manifesto Data Collection. Manifesto Project (MRG/CMP/MARPOR). Version 2018a, Berlin.

Wlezien, C. and Soroka, S. N. (2012) 'Political Institutions and the Opinion-Policy Link', West European Politics 35(6): 1407-1432.

Wratil, C. (2018) 'Modes of Government Responsiveness in the European Union: Evidence from Council Negotiation Positions', European Union Politics 19(1): 52-74.

Wratil, C. (2019) 'Territorial Representation and the Opinion-Policy Linkage: Evidence from the European Union', American Journal of Political Science 63(1): 197-211.

Wratil, C. and Hobolt, S. B. (2019) 'Public Deliberations in the Council of the European Union: Introducing and Validating DICEU', European Union Politics 20(3): 511-531.

Zimmer, C., Schneider, G. and Dobbins, M. (2005) 'The Contested Council: Conflict Dimensions of an Intergovernmental EU Institution', Political Studies 53(2): 403-422. 